Ospina-Alvarez, N., Caetano, M., Vale, C., Santos-Echeandia, J., Prego, R., (2014). Prevalence of tide-induced transport over other metal sources in a geologically enriched temperate estuarine zone (NW Iberian Peninsula). Journal of Geochemical Exploration.

doi: 10.1016/j.gexplo.2014.02.001

\title{
Prevalence of tide-induced transport over other metal sources in a geologically enriched temperate estuarine zone (NW Iberian Peninsula)
}

\author{
N.Ospina-Alvareza, b*, M.Caetanoc, C. Valec, J.Santos-Echeandía ${ }^{a}$, and R. Prego ${ }^{a}$ \\ a Institute of Marine Research (IIM-CSIC). 36208 Vigo, Spain. \\ b University of Warsaw. Faculty of Chemistry. 02-093 Warsaw, Poland. \\ c Portuguese Sea and Atmosphere Institute (IPMA). 1400 Lisbon, Portugal
}

\begin{abstract}
Tide-induced transport, diffuse fluxes and river inputs of arsenic, cobalt, chromium, manganese and nickel were studied in an estuarine zone located at the Ria of Ortigueira in the Galician coast of NW Spain to evaluate comparatively the magnitude of trace-element inputs in the estuarine ecosystem. Short-sediment cores and flooding water were collected at the intertidal area of La-Caleira Inlet in spring and summer 2008 during the first 50 min of tidal inundation. High concentrations of dissolved chromium (up to $23 \mathrm{nM}$ ) and nickel $(256 \mathrm{nM}$ ) were found in waters of the Lourido River during 2008. Chromium (up to $795 \mathrm{mg} \cdot \mathrm{kg}$ 1) and nickel (up to $533 \mathrm{mg} \cdot \mathrm{kg}^{-1}$ ) in surface sediments of the study area were also high, pointing to natural geological sources (Cape Ortegal Complex). Fluxes associated with molecular diffusion and tide-induced transport across the sediment-water interface were quantified and compared to the river contribution. Mean fluxes from the Lourido River were $0.03 \mu \mathrm{mol} \cdot \mathrm{m}^{-2} \cdot \mathrm{d}^{-1}$ for As, $0.02 \mu \mathrm{mol} \cdot \mathrm{m}^{-2} \cdot \mathrm{d}^{-1}$ for Co, $0.43 \mu \mathrm{mol} \cdot \mathrm{m}^{-}$ ${ }^{2} \cdot \mathrm{d}^{-1}$ for $\mathrm{Cr}, 0.72 \mu \mathrm{mol} \cdot \mathrm{m}^{-2} \cdot \mathrm{d}^{-1}$ for $\mathrm{Mn}$ and $5.98 \mu \mathrm{mol} \cdot \mathrm{m}^{-2} \cdot \mathrm{d}^{-1}$ for Ni. Diffusive fluxes were negative which indicates the flow of trace elements towards the sediment $-0.47 \pm 0.12 \mu \mathrm{mol} \cdot \mathrm{m}^{-2} \cdot \mathrm{d}^{-1}$ for As; $-0.007 \pm 0.001$ $\mu \mathrm{mol} \cdot \mathrm{m}^{-2} \cdot \mathrm{d}^{-1}$ for Co; $-0.003 \pm 0.009 \mu \mathrm{mol} \cdot \mathrm{m}^{-2} \cdot \mathrm{d}^{-1}$ for $\mathrm{Cr} ;-5.44 \pm 1.65 \mu \mathrm{mol} \cdot \mathrm{m}^{-2} \cdot \mathrm{d}^{-1}$ for $\mathrm{Mn}$; and $-0.02 \pm 0.05$ $\mu \mathrm{mol} \cdot \mathrm{m}^{-2} \cdot \mathrm{d}^{-1}$ for $\mathrm{Ni}$. Tide-induced transport of trace metals was up to four orders of magnitude greater than diffusive fluxes. The contributions of trace elements to the estuarine zone from fluvial and benthic origin were quantified, emphasizing the importance of tide-induced transport in estuarine systems.
\end{abstract}

Keywords: Flooding water, pore water, diffusive fluxes, trace elements, Cape Ortegal Complex, Northern Galician Rias 


\section{Introduction}

Rivers are considered one of the main sources of trace elements from land to the coastal environments. This transport depends on the nature of the river basins and physical and chemical characteristics of water. Weathering, anthropogenic materials and atmospheric deposits are the main sources of dissolved and particulate trace elements to estuaries (Martin et al., 1980; Viers et al., 2007). During weathering, mineral constituents are released to natural waters and metals may be transported in the dissolved form or adsorbed on suspended material, incorporated in the lattice of freshly formed inorganic compounds such as $\mathrm{Al}, \mathrm{Fe}$ and $\mathrm{Mn}$ (oxy)hydroxides or sorbed in organic matter. Particles originating in the catchments settle in margins, flood plains and other low hydrodynamic sites.

Besides rivers, bottom sediments of estuaries and rias may also act as a source or a sink of trace elements to the water column. In subtidal sediments it has been recognized that bioirrigation/bioturbation (Cardoso et al., 2008; Meysman et al., 2006) and molecular diffusion (Man et al., 2004; Ospina-Alvarez et al., 2014; Zabel et al., 1998) are known to promote the exchange of solutes across the sediment-water interface. However, most of the estuaries and rias are characterized by extensive intertidal areas. These sediments are subjected to changes of pressure, temperature, light exposure and solute concentration (Hammond, 2001) every tidal cycle. The periodic inundation of sediments induces the export of nutrients and trace elements to the water column (Caetano et al., 2007; Huettel et al., 1998), the supply of oxygen to deeper sediment layers (Kener and Wallmann, 1992) and the removal of solutes to the solid fraction (Falçao and Vale, 1995). Resuspension and mixing associated with tides and wind episodes induce the mixing of surface sediments with the overlying water promoting changes in the sorption equilibrium (Simon, 1989).

Most researches have addressed separately inputs from rivers or fluxes across the sediment-water interface. However, the relevance of each process that introduces trace elements in the coastal ecosystems has not been studied. Thus, the main goal of this work was to compare the magnitude of trace-element input from freshwaters, molecular diffusion fluxes and tide-induced transport. This study reports the concentration of arsenic, cobalt, chromium, manganese and nickel in (i) river water, (ii) surface sediments and (iii) flooding and pore water during the first $50 \mathrm{~min}$ of tidal inundation. River inputs, diffuse fluxes and tide-induced transport of trace elements were estimated in order to evaluate their importance to the total budget in the ria ecosystem.

\section{Material and methods}

\subsection{Study area}

Rias are coastal inlets formed during the Flandrian Transgression by the drowning of a former river valley characterized by irregular coastlines and exposed rock platform (Goudie, 2004). Several ria-type systems are located at the Galician coast of Spain (NW Iberian Peninsula). The Ria of Ortigueira represents one of the largest intertidal systems of the Northern Galician Rias (Torre-Enciso, 1958). The ria covers an area of $38 \mathrm{~km}^{2}$, considering the $30-\mathrm{m}$ depth isoline as the ria-shelf boundary, of which $48 \%$ corresponds to the intertidal area. It is a mesotidal systems dominated by marine processes, and contrasting geological 
features characterize its surrounding area. Located at the west of the ria, the Cape Ortegal complex is rich in mafic and ultramafic rocks and eastward, the Ollo-de-Sapo domain, is composed of metamorphic (mostly gneisses) and granite-type rocks (Aparicio et al., 1987; IGME, 1977) (Figure 1). The main fluvial sources are the Mera (basin area: $127 \mathrm{~km}^{2}$ ) and Lourido River $\left(10 \mathrm{~km}^{2}\right)$, which present a hydrological and hydrochemical behavior similar to that of other basins in the area (Bernárdez et al., 2013).

\subsection{River water sampling}

All plastic labware employed for sampling, storage and sample treatment was previously acid-washed for $48 \mathrm{~h}$ in $50 \% \mathrm{HNO}_{3}$ and rinsed with Milli-Q water $(18.2 \mathrm{M} \Omega \mathrm{cm})$, then transferred into a container filled with $10 \% \mathrm{HCl}$ for at least a week. Labware was rinsed several times with Milli- $Q$ water and dried into a laminar flow cabin (ISO Class 5) before use. One liter LDPE bottles were filled with Milli-Q water at pH 2 until use. Sampling was performed following clean techniques for trace element analysis (GEOTRACES, 2010; US-EPA, 1996). Monthly water samples were collected in the Lourido and Mera rivers (mean flow 2008: 0.5 and $6.0 \mathrm{~m}^{3} \cdot \mathrm{s}^{-1}$ ) from January to December 2008.

Salinity and temperature were measured in situ using a WTW MultiLine P4 Set (error range \pm 0.1 ). Dissolved oxygen concentration and their saturation percentages were determined within $24 \mathrm{~h}$ after collection. Samples for dissolved organic carbon (DOC) were taken into $50 \mathrm{~mL}$ polyethylene bottles previously cleaned and washed with $\mathrm{HCl}$, and then frozen at $-20^{\circ} \mathrm{C}$ until analysis. Samples for trace elements were collected in 1-L LDPE bottles previously acid-washed and rinsed with Milli-Q water.

At a clean portable-laboratory and within four hours after collection (Chapman, 1992), samples were separated into dissolved and particulate fractions in a laminar flow cabinet (ISO Class 5) by filtration through Pall-Gelman polycarbonate membranes $(0.45 \mu \mathrm{m})$, previously acid washed (Suprapur $\mathrm{HCl} 1 \%$ ) and weighed. Samples for dissolved trace elements analysis were acidified with Suprapur $\mathrm{HNO}_{3}(\mathrm{pH}<2)$. Afterward membranes were dried, weighed again and suspended particulate matter (SPM) calculated. Filters were placed into plastic petri dishes and stored at $-20^{\circ} \mathrm{C}$ until digestion for particulate metal analysis.

\subsection{Surface sediment sampling}

Six samples of surface sediment (sites A to F, Fig. 1) were collected in the Ria of Ortigueira on July 2007, on board the R/V Lura and small boats, by means of a Van Veen grab sampler. In the intertidal area, sediments were collected by hand. Subsequently, the uppermost sediment layer $(0-1 \mathrm{~cm})$ was withdrawn with a plastic spatula and stored in pre-cleaned LDPE vials at $4^{\circ} \mathrm{C}$. Sediments were dried at $50^{\circ} \mathrm{C}$ and the coarse fraction was separated using a $2 \mathrm{~mm}$ sieve. The $<2 \mathrm{~mm}$ fraction was homogenized by dry milling in an agate mortar. Samples were stored for further analysis. Sediments were classified according to the grain size by dry sieving (CISA RP-09) following the Udden-Wentworth scale, and the percentage of mud $(<0.63 \mathrm{~mm}$ fraction) in each sample was determined.

\subsection{Sediment cores and tidal inundation water sampling}

Sediment cores of $30 \mathrm{~cm}$ length and $6 \mathrm{~cm}$ diameter were collected in sediments from the Lourido River discharge area (La-Caleira inlet; $43^{\circ} 42.82^{\prime} \mathrm{N}-7^{\circ} 52.69^{\prime} \mathrm{W}$; Fig. 1), at low tide during two sampling 
campaigns (April $10^{\text {th }}$ and July 21st, 2008). During the exposition of sediments to the atmosphere, water was collected (t1) from the main channel of the ria (approx. $1 \mathrm{~m}$ from the core-sampling site). Subsequently as inundation started sediment cores and correspondent flooding water were collected during the first 50 minutes of tidal flood $(t 5, t 10, t 15, t 20$ and $t 50)$. A four-man team performed the sampling in less than 3 minutes per core collection with minor sediment perturbation. Flooding water was collected $1 \mathrm{~cm}$ above the sediment into acid pre-cleaned syringes with $0.45 \mu \mathrm{m}$ polycarbonate filter. Samples were acidified with suprapur $\mathrm{HNO}_{3}(\mathrm{pH}<2)$. After each core sampling sediments were quickly sliced into 2-cm thickness layers. According to Caetano et al. (1995), no significant changes on redox sensitive elements were observed with this sampling procedure. Sliced sediments were directly transferred into pre-cleaned $50 \mathrm{~mL}$ Eppendorf® tubes avoiding the air presence inside. Pore waters were separated by centrifugation during $20 \mathrm{~min}$ at $4500 \mathrm{rpm}\left(4^{\circ} \mathrm{C}\right)$ using a UniCen 15D (Herolab) centrifuge. Filtration and subsequent manipulation of samples were carried out in a clean laminar flow ISO Class 5. Pore water was collected with plastic syringes, filtered through $0.45 \mu \mathrm{m}$ membranes and immediately acidified with Suprapur $\mathrm{HNO}_{3}(\mathrm{pH}<2)$ and preserved under refrigeration until analysis.

Sediment porosity was estimated using the top two centimetres of sediments and then dried at $50^{\circ} \mathrm{C}$ during one week until constant weight. Water depth and tide height during sampling were determined by barometric difference by means of an AQUAlogger 520 sensor (Aquatec). These data were then used in the calculation of fluxes across the sediment-water interface.

\subsection{Analytical methodologies}

\subsubsection{Water samples}

Dissolved oxygen concentrations in river samples (error range \pm 0.2 ) were determined at the clean portable-laboratory within $24 \mathrm{~h}$ after collection, using an automatic titrator (702-SM Titrino, Metrohm) according to the Winkler method (Aminot, 1983). DOC analysis was carried out at the Laboratory of Marine Biogeochemistry Unit (INTECMAR, Vilagarcía de Arousa) using a Shimadzu TOC-VCSH analyzer with high temperature catalytic oxidation (HTCO) and non-dispersive infrared detection (NDIR) following the procedure described by (Alvarez-Salgado and Miller, 1998). Analyses were accredited by ENAC (Spanish National Accreditation Body) according to the norm UNE-EN ISO/IEC 17025:2005.

Particulate metals in river samples were determined by ETASS (Electrothermal atomic absorption spectrometry) in a Varian SpectrAA-220 spectrometer equipped with Zeeman background correction. Prior to analysis, filters containing SPM were microwave-digested (Milestone 1200 Mega) in Teflon bombs using a mixture of $\mathrm{HNO}_{3}$ and $\mathrm{HF}$ according to US-EPA method 3052. Dissolved metals in river and estuarine samples (tidal and pore water) were determined in a quadrupole inductively coupled plasma mass spectrometer (Thermo Elemental, X-Series) equipped with a Peltier Impact bead spray chamber and a concentric Meinhard nebulizer. Quality Control (QC) solutions for trace elements were run every 10 samples and ${ }^{115}$ In was used as internal standard to quantify metal concentrations. Procedural blanks were less than $1 \%$ of element concentrations in the samples. As ICP-MS (Inductively coupled plasma mass spectrometry) is highly sensitive to interferences by high salt contents, estuarine samples were diluted (between 1:1 and 1:10) with Milli-Q water. The accuracy of the analytical procedure was controlled by the 
analysis of SLRS-4 (river water) and SLEW-3 (estuarine water) certified reference material (NRC, Canada) (Table 1). Limit of detection (LOD) of the analytical procedure was calculated as standard deviation of replicate analyses of a blank $(n=30)$ corrected by student's t- statistic (at $97.5 \%$ confidence; $d f=n-1)$. LOD of dissolved trace elements were: $0.13 \mathrm{nM}$ for As, $0.03 \mathrm{nM}$ for Co, $0.19 \mathrm{nM}$ for $\mathrm{Cr}, 0.55 \mathrm{nM}$ for $\mathrm{Mn}$ and 0.68 $\mathrm{nM}$ for Ni.

\subsubsection{Surface sediment samples}

Concentrations of organic carbon (POC) and total organic nitrogen (PON) in suspended particulate matter of the Ria of Ortigueira were measured directly in duplicate samples, after removal of the carbonates by sample digestion with $\mathrm{HCl}$ at $80^{\circ} \mathrm{C}$. Analyses were performed with an EA1108 elemental $\mathrm{CNH}$ analyzer (Carlo Erba Instruments). Ratios of C:N (mol:mol) were calculated in terms of POC:PON.

Trace elements in sediments ( $<2 \mathrm{~mm}$ size fraction) were determined by ICP-MS according to the following methodology. Before analysis surface sediment samples $(\approx 100 \mathrm{mg})$ were completely digested with $6 \mathrm{~cm}^{3}$ of $\mathrm{HF}(40 \%)$ and $1 \mathrm{~cm}^{3}$ of Aqua Regia (HCl-36\%: $\mathrm{HNO}_{3}-60 \% ; 3: 1$ ) in closed Teflon bombs at $100^{\circ} \mathrm{C}$ for $1 \mathrm{~h}$ (Rantala and Loring, 1975). The bomb contents were evaporated to near dryness in Teflon vials, redissolved with $\mathrm{HNO}_{3}$, heated for $20 \mathrm{~min}$ at $75^{\circ} \mathrm{C}$ and diluted to $50 \mathrm{~cm}^{3}$ with Milli-Q water (Caetano et al., 2009). Certified reference material PACS-2 (marine sediment; NRC Canada) was analyzed to assess the accuracy of the analytical procedure (Table 1).

The labile fraction in surface sediments (sites A to F, Fig. 1) was determined according to Quevauviller et al. (1997) by the first step sequential extraction scheme of the Standards, Measurement and Testing program (SM\&T, formerly BCR) of the EU Commission. Pre-treatment and analysis of samples were carried out in an ultra-clean laboratory (ISO Class 7) and in a laminar flow cabin (ISO Class 5). Aliquots of dry sediment fine fraction $(\approx 0.5 \mathrm{~g})$ were treated with $20 \mathrm{~mL}$ of $0.11 \mathrm{M}$ acetic-acid and a magnetic shaker (MI Variel ALC) was used to keep the sediment sample in suspension during extraction $\left(16 \mathrm{~h}\right.$ at $\left.22^{\circ} \mathrm{C}\right)$. After extraction, sediments were centrifuged for $20 \mathrm{~min}$ at $3000 \mathrm{rpm}\left(22^{\circ} \mathrm{C}\right)$ using a Beckman Avanti J-25 centrifuge and the supernatant from the solid phase was decanted and stored at $4{ }^{\circ} \mathrm{C}$ until analysis. Labile $\mathrm{Cr}$ and $\mathrm{Ni}$ were analyzed by GFAAS in a Varian SpectrAA 220-Zeeman (CSIC, Vigo). The precision as relative standard deviation (RSD) was always less than 5\%. Certified reference material BCR-701 (freshwater sediment, IRMM Belgium) was analyzed to check the first step of SM\&T metal extraction (Table 1). LOD of particulate trace elements, calculated as three times the standard deviation of the blanks, were: $0.25 \mu \mathrm{g} \cdot \mathrm{kg}^{-1}$ for Co, $0.05 \mu \mathrm{g} \cdot \mathrm{kg}^{-1}$ for $\mathrm{Cr}$ and $0.12 \mu \mathrm{g} \cdot \mathrm{kg}^{-1}$ for $\mathrm{Ni}$.

\section{Calculations}

\subsection{Sediment porosity}

Porosity was calculated following the equation (Berner, 1980): 


$$
\Phi=\frac{W_{p w}}{W_{p w}+\left(\frac{W_{S}}{G_{S}}\right)}
$$

were $\Phi$ is the porosity, $W_{\mathrm{pw}}$ is the weight of the pore water expressed in grams, $\mathrm{W}_{\mathrm{s}}$ is the weight in grams of the dry sediment and $\mathrm{G}_{\mathrm{s}}$ is the specific gravity of the sediment, which is assumed as a constant of 2.65 (Berner, 1980).

\subsection{Estimation of diffusive fluxes}

Diffusive fluxes (DF) across the sediment-water interface were estimated according to Fick's first law of diffusion (Berner, 1980), using the equation:

$$
D F\left(\mu \mathrm{mol} \cdot \mathrm{m}^{2} \cdot \mathrm{s}^{-1}\right)=-\Phi^{3} \cdot D_{j} \cdot\left[\frac{C_{p w}-C_{f w}}{\Delta x}\right]
$$

where $\Phi$ is the porosity (dimensionless); $D_{j}$ is the diffusion coefficient $\left(D_{j}^{0}\right.$ or $\left.D_{j}^{*}\right)$ of a solute at a given temperature $\left(\mathrm{cm}^{2} \cdot \mathrm{s}^{-1} \times 10^{-1}\right) ; \mathrm{C}_{\mathrm{pw}}$ is the trace element concentration $(\mu \mathrm{M})$ in pore water of the topmost sediment layer at $\mathrm{t}=0 ; \mathrm{C}_{\mathrm{fw}}$ is the trace element concentration $(\mu \mathrm{M})$ in flooding water; and $\Delta \mathrm{x}$ is the thickness of the water-sediment diffusive layer (equal to $1.5 \mathrm{~cm}$ in this study which is equivalent to the distance between overlying and pore water). The diffusion coefficients $\left(D_{j}\right)$ for As, Co, Cr, Mn and Ni were calculated by interpolation of known coefficients at a given temperature with the temperature measured on the sampling days. As contrasting conditions of salinity were found for the sampling carried out in spring and summer, two diffusion coefficients were considered (Table 2). $\mathrm{D}_{j}^{0}$ coefficients were used to calculate diffusive fluxes in April, and $\mathrm{D}_{j}^{*}$ (coefficients for sea water) for fluxes in July. $\mathrm{D}_{\mathrm{j}}{ }^{*}$ coefficients were determined according to Li and Gregory (1974), with the equation:

$$
D_{j}^{*}=D_{j}^{0} \cdot \frac{n^{0}}{n_{35}}
$$

where $D_{j}{ }^{0}$ is the diffusion coefficient previously calculated at the sampling temperature; and $n^{0} / n_{35}$ is the extrapolated value of the relation of the water $\left(n^{0}\right)$ and seawater $\left(n_{35}\right)$ viscosity $\left(n^{0} / n_{35}\right.$ is assumed as 0.92 at $25^{\circ} \mathrm{C}$ and 0.95 at $0^{\circ} \mathrm{C} ; \mathrm{Li}$ and Gregory 1974 ). Differences between diffusion coefficients $\mathrm{D}_{j}{ }^{0}$ and $\mathrm{D}_{j}{ }^{*}$ were not statistically significant. Diffusive fluxes obtained with Eq. 2 were converted to daily fluxes per square meter $\left(\mathrm{nmol} \cdot \mathrm{m}^{-2} \cdot \mathrm{d}^{-1}\right)$, taking into account that semi-diurnal tidal cycles inundate the intertidal area twice a day, thus, sediments are also submerged twice per day.

\subsection{Estimation of tide-induced transport}

Tide-induced transport $\left(\mathrm{T}_{\mathrm{t}}\right)$ was estimated with a modified equation based on Ospina-Alvarez et al. (2014): 


$$
T_{t}\left(\mu \mathrm{mol} \cdot \mathrm{m}^{2} \cdot d^{-1}\right)=\sum\left[\left(\frac{C_{t 2}-C_{t 1}}{2}\right)-C_{r}\right] \cdot\left(h_{t 2}-h_{t 1}\right) \cdot d \cdot k
$$

where $C_{t 2}$ and $C_{t 1}$ are the trace element concentration in the pore water $(\mu M)$ at each sampling time $\left(t_{1}, t_{5}\right.$, $\left.t_{10}, t_{n}\right), C_{r}$ is the residual concentration in $\mu M$ (lowest value measured in the flooding water), $h$ is the water depth $(\mathrm{cm})$ at the same times, $\mathrm{d}$ is a factor used to express the values in daily induced transport considering the semidiurnal tidal regime $(d=2)$, and $k$ is a constant to express the values per square meter $(\mathrm{k}=10)$. Tide-induced transport of trace elements was calculated for the first 50 minutes of inundation. Positive values indicate a flux from the sediment to the overlying water.

\subsection{Fluvial contribution of dissolved trace elements to the ria}

In order to determinate the contribution of dissolved trace elements from the Lourido River to the LaCaleira Inlet, the Lourido fluvial discharge $\left(\mathrm{F}_{\mathrm{L}}\right)$ was calculated following the equation:

$$
F_{L}\left(\mu \mathrm{mol} \cdot m^{2} \cdot d^{-1}\right)=\left(Q_{L} \cdot C_{L} \cdot S^{-1}\right) \cdot k
$$

where $\mathrm{Q}_{\mathrm{L}}$ corresponds to the Lourido River flow $\left(\mathrm{m}^{3} \cdot \mathrm{s}^{-1}\right), \mathrm{C}_{\mathrm{L}}$ to the trace element concentrations $(\mathrm{nM})$ in the Lourido water; $\mathrm{S}$ is surface of the La-Caleira Inlet $\left(0.686 \mathrm{~km}^{2}\right)$ and $\mathrm{k}$ is a unit homogeneity constant to express the values per day and square meter $(\mathrm{k}=0.0864)$. Daily flow of Lourido River was estimated from the neighboring Mera River according to the ratio between the total basin areas of both rivers $(0.0806)$. The daily flows of Mera River were provided by Augas de Galicia (Station 443; (Augas de Galicia, 2011).

\subsection{Statistical analysis}

Statistical analyses were carried out using GraphPad Prism 4.0 for Mac OS-X. Differences in trace element concentrations in rivers through sampling periods were checked by means of a non-parametric WilcoxonMann-Whitney test (Ott and Longnecker, 2008). Mann-Whitney analysis was used to detect differences in: (i) trace element concentration in flooding and pore water, and (ii) diffusive fluxes and tide-induced transport during the sampling dates. Variability in concentrations through sediment layers and inundation times was tested using a non-parametric Kruskal-Wallis test followed by a Dunn's post-hoc multiple comparison test. Outliers were identified by a Grubbs'test and removed from the data set. Results presented are expressed as the mean \pm standard deviation.

\section{Results}

\subsection{Fluvial inputs}

Lourido River was very well oxygenated throughout the year with saturation above $90 \%$. Temperature and $\mathrm{pH}$ were $14.2 \pm 3.6^{\circ} \mathrm{C}$ and $7.2 \pm 0.5$ respectively (Fig. 2). Mean DOC was $175 \pm 54 \mu \mathrm{M}$, with higher values in April (up to $260 \mu \mathrm{M}$ ). Similar ranges of oxygen saturation, temperature and $\mathrm{pH}$ were observed in the Mera River, but DOC values were lower than in the Lourido River during all through the year.

The concentrations of dissolved trace elements were relatively constant during 2008 in the Lourido and Mera rivers with no significant differences (Wilcoxon-Mann Whitney test, $p>0.05$ ) between concentrations of each river from January to March and from May to July. Both periods of three months 
were considered for comparisons with respect to the diffusive and tide-induced sediment-water exchanges of dissolved trace elements. Figure 2 gives the ranges of arsenic, cobalt, chromium, manganese and nickel dissolved concentrations in Lourido during 2008. Significant different concentrations of all elements were found for Lourido River (median 1st semester-2008: As $1.1 \mathrm{nM}$; Co $0.57 \mathrm{nM}$; Cr $9.8 \mathrm{nM}$; Mn $25 \mathrm{nM}$ and Ni $163 \mathrm{nM}$ ) and Mera River (median 1 ${ }^{\text {st }}$ semester-2008: As $3.2 \mathrm{nM}$; Co $1.6 \mathrm{nM}$; Cr 1.4 nM; Mn 51 $\mathrm{nM}$ and $\mathrm{Ni} 14 \mathrm{nM}$ ) (Mann Whitney test, $\mathrm{p}<0.01$ ). Dissolved arsenic, cobalt and manganese were higher in the Mera River (Fig. 2), while concentrations of chromium and nickel were $80 \%$ higher in the Lourido River than in the Mera River. This pattern was also found in the particulate fraction with increased concentrations of particulate chromium and nickel in the Lourido River (Fig. 2).

\subsection{Surface sediment characteristics}

The characterization of the surface sediments at the Ria of Ortigueira is presented in Table 3. Sediment composition of the Ria of Ortigueira was dominated by medium sands, with an increment of mud in the intertidal zone. Specifically, high mud content $(<63 \mu \mathrm{m}$ fraction) was found at the La-Caleira Inlet (site D, Table 3). Samples of the site D showed higher concentrations of POC, although C:N ratios were generally similar for all samples $(11 \pm 2)$. Concentrations of trace elements in surface sediments were in the same concentration range (Table 3), however labile chromium and nickel were up to two orders of magnitude higher at the La-Caleira Inlet than in the other sites located through the head and mouth of the ria (sites A, B, E, F).

\subsection{Pore water concentration profiles}

The maximum concentrations in pore water during April and July reached 1378 and $607 \mathrm{nM}$ for As, 26 and $18 \mathrm{nM}$ for Co, 169 and $26 \mathrm{nM}$ for $\mathrm{Cr}, 23257$ and $4474 \mathrm{nM}$ for Mn, 377 and $175 \mathrm{nM}$ for Ni, respectively. A wide range of metal concentrations was found in April while in summer concentrations showed narrower variability (Fig. 3). In fact, significantly higher concentrations of cobalt, chromium and manganese (Mann Whitney test, $\mathrm{p}<0.01$ ) were recorded in April. The concentrations were generally conservative and not significant differences through sediment layers were found for nickel on April (Kruskal-Wallis, $\mathrm{p}>0.05$ ) and for arsenic and chromium in both samplings (Kuskal-Wallis, $\mathrm{p}>0.05$ ).

By contrast, differences in pore water concentration in sediment layers were observed in July for cobalt, manganese and nickel. Strong variations were found in cobalt values through the different sediment layers in April (Kruskal-Wallis, p <0.05) and July (Kruskal-Wallis, p <0.001). A gradual decrease with depth was clearly observed in the cobalt profile, whose values decreased from $18 \pm 4 \mathrm{nM}$ (April) and $12 \pm$ $4 \mathrm{nM}$ (July) at surface sediments $(0-2 \mathrm{~cm})$ to $10 \pm 5 \mathrm{nM}$ (April) and $4 \pm 1 \mathrm{nM}$ (July) into deeper sediment layers $(6-8 \mathrm{~cm})$. The above tendency was also observed for manganese, but with a sharp change in the first $3 \mathrm{~cm}$ of the sediment layer (Fig. 3). The difference of manganese values across the sediment layers was up to four times higher in the most superficial layer than in deeper sediments, with manganese concentrations of $9907 \pm 6956 \mathrm{nM}$ (April) and $2209 \pm 982 \mathrm{nM}$ (July) in the 0-2 cm layer and $3192 \pm 1164$ $\mathrm{nM}$ (April) and $2000 \pm 320 \mathrm{nM}$ (July) in the 6-8 cm layer. As observed in cobalt and manganese, nickel concentrations on July also presented significant differences between sediment layers (Kruskal-Wallis, $p$ $<0.01)$. 
During the spring sampling (water temperature: $9.6^{\circ} \mathrm{C}$; salinity: 0.4 ), the highest concentrations of arsenic, cobalt, chromium and nickel were observed before the arrival of the tide $(t=0)$, but this pattern was not observed during the summer sampling (water temperature: $19.1^{\circ} \mathrm{C}$; salinity: 30.1 ) (Fig. 3). The manganese had a different variability, with higher values at the end of the spring flooding period $(t=50)$.

Figure 4 shows the temporal evolution of trace elements in flooding water and sediment pore water during the first $50 \mathrm{~min}$ of tidal inundation. Values of arsenic in pore water during April decreased four folds during the first 15 minutes of inundation (up to $\approx 300 \mathrm{nM}$ ) followed by a stabilization of concentrations (Fig. 4). Dunn's post-test showed that differences in concentrations before $(\mathrm{t}=0)$ and after $(\mathrm{t}=50)$ tidal inundation were significant at $\mathrm{p}<0.01$ level. In July, arsenic values remained homogeneous around $\approx 400 \mathrm{nM}$, with an increase in surface sediments $(0-2 \mathrm{~cm}$ ) at the end of tidal flooding (up to 599 $\mathrm{nM})$.

The time course variation of cobalt in April followed the same pattern observed for arsenic; similar values were measured between 20 and 50 minutes of inundation preceded by a decrease of concentrations within the first 20 minutes (up to $6 \mathrm{nM}$ ). In July, minor variations of cobalt was also found (Kruskal-Wallis, $\mathrm{p}>0.05$ ) (Fig. 4).

As observed in time evolution of arsenic and cobalt during April, concentrations of chromium on the same date were higher at air-exposed conditions $(\mathrm{t}=0)$. Values decreased up to $90 \%$ during the first 15 minutes, remaining in homogeneous concentrations $(\approx 13 \mathrm{nM})$ until the end of tidal flooding. In July, chromiun concentrations in pore water were relatively constant $(\approx 15 \mathrm{nM})$ within the first 20 minutes, followed by a decrease between the 20 and 50 minutes of inundation (up to $1 \mathrm{nM}$ ) (Fig. 4).

Minor variations were found in pore water concentrations of manganese in July. Values varied between 1448 and $4474 \mathrm{nM}$ during the studied flooding period. Conversely, a sharp decrease was found in the first 15 minutes of inundation for all layers in April. Manganese concentrations from the top to the bottom decreased up to $81 \%$ during this period.

During spring, nickel concentrations in pore water decreased as inundation starts, remained constant after 15 minutes of tidal inundation $(\approx 160 \mathrm{nM})$. In summer, the concentrations were homogenous throughout the flood period $(\approx 130 \mathrm{nM}$ ) (Kruskal-Wallis, p >0.05) (Fig. 4). Values of nickel observed in both sampling dates were similar to those measured in the Lourido River (see Fig. 2).

\subsection{Trace elements in flooding water}

Trace element concentrations in flooding water throughout this study were $136 \pm 118 \mathrm{nM}$ for As, $5.35 \pm$ $5.10 \mathrm{nM}$ for Co, $12.8 \pm 12.1 \mathrm{nM}$ for $\mathrm{Cr}, 252 \pm 347 \mathrm{nM}$ for $\mathrm{Mn}$ and $102 \pm 77 \mathrm{nM}$ for Ni. Differences in the arsenic concentrations in flooding water during April and July were significant at $p<0.01$ (Mann-Whitney test), by contrast, concentrations of cobalt, chromium, manganese and nickel showed no differences during sampling dates.

In spring, arsenic and manganese values were up to three orders of magnitude lower in flooding water than in pore water (Mann Whitney test, $\mathrm{p}<0.001$ ), whereas chromium and nickel were up to two orders of magnitude lower in flooding water (Mann Whitney test, $\mathrm{p}<0.01$ ). In the summer season, arsenic and 
cobalt in flooding and pore water were in the same order of magnitude, while chromium, manganese and nickel were generally lower in flooding water by one order of magnitude (Fig. 4).

\section{Discussion}

Some of the trace elements analyzed (As, Co, and Mn) in sediments of the Ria of Ortigueira and its adjacent intertidal flats (Table 3) were within the range reported in other coastal areas worldwide (Rae, 1997; Silva et al., 2009). Otherwise, chromium and nickel values were greater than those reported for unpolluted soils (Bruland, 1983; US-EPA, 1985), and even higher than the content found in samples in highly contaminated areas (Abrahim and Parker, 2002; Tuncer et al., 2001). Values of both metals were also higher than those reported in surface sediments of other Galician rias (Caetano et al., 2009; Carral et al., 1995; Cobelo-Garcia and Prego, 2003). The high values of chromium found in surface sediments of the Ria of Ortigueira, can be associated with weathering of mafic and ultrabasic rocks, as found by Yücesoy and Ergin (1992) in surface sediments from the southern Black Sea. The composition of the Cape Ortegal complex, rich in chromium and nickel minerals as chromites, chromospinels, dunites, pentlandites (Arenas et al., 2009; Gibbons and Moreno, 2002), is a natural source of these elements. Previous studies in saltmarsh soils of the Ria of Ortigueira, reported a high enrichment factor of chromium and nickel in the first $10 \mathrm{~cm}$ of the sediment, linking these high values to the influence of ultramafic serpentinized rocks present in the area (Otero et al., 2000).

Fluvial concentrations also confirm that the Cape Ortegal complex is an important source of dissolved chromium and nickel to the Ria of Ortigueira. The range for dissolved arsenic, cobalt and manganese observed in the Lourido River, were within the range reported in rivers worldwide (Gaillardet et al., 2005), but lower than those observed in other Galician fluvial sources (Salminen, 2005). Nevertheless, values of chromium and nickel were several times higher in the Lourido River than in other Galician and European rivers (Prego et al., 2006; Salminen, 2005). Particulate suspended matter of Lourido River also shows this enrichment pattern (Figure 2), with concentrations of both elements even greater than those reported in such rivers as the Ganges (central Asia), Brahmaputra (South Asia) or Yakima (NW US) whose waters flow through important geological zones (Alagarsamy and Zhang, 2005; Morace et al., 1999). Thus the observed concentrations of $\mathrm{Cr}$ and $\mathrm{Ni}$ in the dissolved fraction and suspended particulate matter may be related to the nature of their basins that cross the Cape Ortegal Complex. This geological feature contains minerals enriched in both metals (Gent et al., 2005) that are transported to the Ria of Ortigueira. Due to the absence of anthropogenic contamination in the region, one may consider that Lourido River is naturally enriched in both metals (Prego et al., 2014). Otherwise, the enrichment of dissolved chromium and nickel was not observed in the Mera River, whose concentrations were in the same range as that measured in other rivers that flow into the Galician coast (Prego and Cobelo-Garcia, 2003). This river crosses a different geological domain (Ollo de Sapo) characterized by metamorphic (mainly gneisses) and granite-type rocks poorer in $\mathrm{Cr}$ and Ni (Aparicio et al., 1987; Marcos, 2004).

The transport of trace elements, in two seasonal periods with small variation in the water flow, was estimated for the principal fluvial source flowing into the sampling area (Lourido River). These variations 
were compared with the sediment-water exchanges associated with molecular diffusion and tide-induced transport.

Trace element fluxes of Lourido River for the two sampling periods are given in Table 4. The general trend of these fluxes was $\mathrm{Ni}>\mathrm{Mn}>\mathrm{Cr}>\mathrm{As}>\mathrm{Co}$, presented differences in the transport of nickel as compared with dissolved trace element discharges by global rivers, whose general trend is $\mathrm{Mn}>\mathrm{Ni}>$ As $>$ Co (GESAMP, 1987). Olias et al. (2006) studied the transport of trace metals to the Huelva estuary and the Gulf of Cadiz (South West Spain) from two rivers heavily affected by acid mine drainage. An important contribution of manganese and nickel from the Odier River was reported in that study, however, despite the high contaminant load estimates, the amount of manganese entering the estuary was always greater than the discharge of nickel. Fluvial discharges of the Lourido River were similar between both periods for arsenic, cobalt and nickel. Conversely, for chromium and manganese, discharges increased two times in May-July (up to $0.66 \mu \mathrm{mol} \cdot \mathrm{m}^{-2} \cdot \mathrm{d}^{-1}$ for $\mathrm{Cr}$ and $0.99 \mu \mathrm{mol} \cdot \mathrm{m}^{-2} \cdot \mathrm{d}^{-1}$ for $\mathrm{Mn}$ ).

Fluxes across the sediment-water due to molecular diffusion are also presented in Table 4. Diffusive fluxes of the trace elements were negative (with the exception of $\mathrm{Cr}$ on July), which implies that the overlying water was a metal source to the sediment when only molecular diffusion was considered. Negative diffusive fluxes of manganese and chromium were also reported by Blasco et al. (2000) in the different sampling stations of the Odiel River, Bay of Cadiz and Barbate River Salt Marshes (SW Iberian Peninsula). Likewise, negative diffusive fluxes of chromium were found in sub-tidal and intertidal areas of San Francisco Bay (Rivera-Duarte and Flegal, 1997), with values similar to those observed in this study. Conversely, the negative diffusive fluxes measured at Ortigueira contrast with those obtained by SantosEcheandia et al. (2009) in the Ria of Vigo (SW Galicia), who obtained positive fluxes of cobalt (up to 0.24 $\mathrm{nmol} \cdot \mathrm{cm}^{-2} \cdot \mathrm{y}^{-1}$ ) and nickel (up to $1.70 \mathrm{nmol} \cdot \mathrm{cm}^{-2} \cdot \mathrm{y}^{-1}$ ). Other studies, in different intertidal areas, also reported positive values in diffusive fluxes of trace elements (Table 5).

In contrast to diffusive fluxes, tide-induced transport was always positive for all the trace elements measured, indicating a release of these elements from the sediment pore water to the water column. Tideinduced transport was greater than diffusive fluxes for all studied trace elements (Wilcoxon-Mann Whitney test, $\mathrm{p}<0.001$ ) (Table 4). Values were up to three orders of magnitude higher for tide-induced transport than for diffusive fluxes, although these differences were even greater for nickel in spring, which reached four orders of magnitude higher (Table 4). Although seepage process was not taken into account during sampling, it is important to remark that hydraulic pressure gradient due to the ebbing tide, could result in a significant flow through the sediment system (Billerbeck et al., 2006; Deborde et al., 2008), which would affect the budget of solutes in the ria.

The fluvial contribution of $\mathrm{Ni}$ has showed increased importance than for the other elements, accounting for $24 \%$ of the total inputs during summer. The above is consistent with the high concentration of this metal measured in the Lourido River (see Fig. 2), which exceeded several times the nickel concentration of $5 \mathrm{nM}$ reported in pristine river water (Prego and Cobelo-Garcia, 2003), suggesting that fluvial transport has a relevant contribution of this metal to the ria. 
Despite submarine groundwater discharge (SGD) being a significant source of trace metals to the ocean, which influence the coastal metal budget (Burnett et al., 2006), there is no evidence of SGD in intertidal areas of the Northern Galician Rias, hence it was not considered as a principal source in this study. Nevertheless, taking into account the variability of coastal metal fluxes due to groundwater concentrations and its non-conservative behavior over short spatial scales (Knee and Paytan, 2011), the consideration of SGD becomes mandatory when benthic flux studies are addressed, especially in areas where the influence of submarine canyons have been previously reported (i.e. Bay of Biscay, Mediterranean Sea, Baltic Sea, etc.)

\section{Conclusions}

Taking into account the contribution of trace elements to the ria, which are from fluvial and benthic origin, the sediment-water exchange due to tidal inundation represent more than $98 \%$ of the total. Thus, tideinduced transport always prevailed over other trace metal sources in the estuarine zone of La-Caleira Inlet. The difference of magnitude observed between sources could be a pattern in the inner ria zones, and emphasizes the importance of considering transport induced by tides when addressing trace metal budgets in estuarine systems. On the other hand, enrichment of trace metals may also occur due to natural contributions, as was observed for $\mathrm{Cr}$ and $\mathrm{Ni}$ related to the presence of chromium and nickel minerals from the Cape Ortegal Complex, thus anthropogenic contributions are not always the main source of trace metals in coastal environments.

\section{Acknowledgments}

Authors acknowledge 'Augas de Galicia' for supplying the river gaging data; to the 'Consellería do Mar (Xunta de Galicia)' for laboratory facilities in Celeiro Harbour; to J. Raimundo (IPIMAR) for their technical assistance in the sampling, analysis and data processing. Dr. Ospina-Alvarez gratefully acknowledges support by a post-doctoral grant from the AXA Research Fund. The CSIC, under the program JAE-Doc (Uunta para la Ampliación de Estudios) co-funded by the Fondo Social Europeo(FSE), is greatly acknowledged for the post-doctoral contract to Dr. Santos-Echeandía and pre-doctoral contract to Dr. Ospina-Alvarez. This article is a contribution to the Spanish LOICZ program and was supported by CICYT under the INTERESANTE project (ref. CTM2007-62546-C03/MAR) and the Spanish-Portuguese Action (ref. 2007PT0021) both in cooperation with the project 'Land-sea exchange of trace metals and its importance for marine phytoplankton in an upwelling coast' (ref. CTM2011-28792-C02) financed by the 'Ministerio de Economía y Competitividad' of Spain. The authors are also grateful to two anonymous referees for their comments and suggestions, which greatly improved the quality of this paper. 


\section{References}

Abrahim, G., Parker, R., 2002. Heavy-metal contaminants in Tamaki Estuary: impact of city development and growth, Auckland, New Zealand. Environmental Geology 42, 883-890.

Alagarsamy, R., Zhang, J., 2005. Comparative studies on trace metal geochemistry in Indian and Chinese rivers. Current Science 89, 299-309.

Alvarez-Salgado, X.A., Miller, A.E.J., 1998. Simultaneous determination of dissolved organic carbon and total dissolved nitrogen in seawater by high temperature catalytic oxidation: conditions for precise shipboard measurements. Marine Chemistry 62, 325-333.

Aminot, A., 1983. Dosage de l'oxygène dissous, in: Aminot, A., Chaussepied, M. (Eds.), Manuel des Analysses Chimiques en Milieu Marin. CNEXO, Brest, pp. 75-92.

Aparicio, A., Sánchez-Cela, V., Cacho, L.E., 1987. Petrological and geochemical considerations of the Cabo Ortegal Complex (NW Spain). Revista Real Academia de Ciencias Zaragoza, 131-162.

Arenas, R., Sánchez Martínez, S., Castiñeiras, P., Jeffries, T.E., Díez Fernández, R., Andonaegui, P., 2009. The basal tectonic mélange of the Cabo Ortegal Complex ( NW Iberian Massif ): a key unit in the suture of Pangea. Journal of Iberian Geology 35, 85-125.

Augas de Galicia, 2011. http://augasdegalicia.xunta.es//gl/7.2.htm.

Bernárdez, P., Ospina-Alvarez, N., Caetano, M., Prego, R., 2013. Fluvial contributions of nutrient salts, dissolved trace elements and organic carbon to the sea by pristine temperate rivers (SW Europe). Environmental Chemistry 10, 42-53.

Berner, R., 1980. Early Diagenesis. A Theoretical Approach. Princeton University Press, Princeton, N.J.

Billerbeck, M., Werner, U., Bosselmann, K., Walpersdorf, E., Huettel, M., 2006. Nutrient release from an exposed intertidal sand flat. Marine Ecology Progress Series 316, 35-51.

Blasco, J., Saenz, V., Gomez-Parra, A., 2000. Heavy metal fluxes at the sediment-water interface of three coastal ecosystems from south-west of the Iberian Peninsula. Science of The Total Environment 247, 189-199.

Bruland, K.W., 1983. Trace elements in sea-water, in: Riley, J.P., Chester, R. (Eds.), Chemical oceanography, 2nd ed. Academic Press, London, pp. 147-220.

Burnett, W.C., Aggarwal, P.K., Aureli, A., Bokuniewicz, H., Cable, J.E., Charette, M.A., Kontar, E., Krupa, S., Kulkarni, K.M., Loveless, A., Moore, W.S., Oberdorfer, J.A., Oliveira, J., Ozyurt, N., Povinec, P., Privitera, A.M.G., Rajar, R., Ramessur, R.T., Scholten, J., Stieglitz, T., Taniguchi, M., Turner, J.V., 2006. Quantifying submarine groundwater discharge in the coastal zone via multiple methods. Science of The Total Environment 367, 498-543.

Caetano, M., Madureira, M., Vale, C., Bebianno, M., Gonçalves, M., 1995. Variations of Mn, Fe and S concentrations in sediment pore waters of Ria Formosa at different time scales. Netherlands Journal of Aquatic Ecology 29, 275-281.

Caetano, M., Madureira, M.J., Vale, C., 2007. Exchange of $\mathrm{Cu}$ and Cd across the sediment-water interface in intertidal mud flats from Ria Formosa (Portugal). Hydrobiologia 587, 147-155.

Caetano, M., Prego, R., Vale, C., de Pablo, H., Marmolejo-Rodriguez, A.J., 2009. Record of diagenesis of rare earth elements and other metals in a transitional sedimentary environment. Marine Chemistry 116, 3646.

Cardoso, P.G., Lillebø, A.I., Lopes, C.B., Pereira, E., Duarte, A.C., Pardal, M.A., 2008. Influence of bioturbation by Hediste diversicolor on mercury fluxes from estuarine sediments: A mesocosms laboratory experiment. Marine Pollution Bulletin 56, 325-334.

Carral, E., Puente, X., Villares, R., Carballeira, A., 1995. Background heavy metal levels in estuarine sediments and organisms in Galicia (northwest Spain) as determined by modal analysis. Science of The Total Environment 172, 175-188.

Chapman, D., 1992. Water quality assessments. Chapman \& Hall, University Press, Cambridge.

Cobelo-Garcia, A., Prego, R., 2003. Heavy metal sedimentary record in a Galician Ria (NW Spain): background values and recent contamination. Marine Pollution Bulletin 46, 1253-1262.

Deborde, J., Anschutz, P., Auby, I., Glé, C., Commarieu, M.-V., Maurer, D., Lecroart, P., Abril, G., 2008. Role of tidal pumping on nutrient cycling in a temperate lagoon (Arcachon Bay, France). Marine Chemistry 109, 98-114. 
Falçao, M., Vale, C., 1995. Tidal flushing of ammonium from intertidal sediments of Ria Formosa, Portugal. Netherlands Journal of Aquatic Ecology 29, 239-244.

Gaillardet, J., Viers, J., Dupré, B., 2005. Trace Elements in River Waters, in: Drever, J.I. (Ed.), Treatise on Geochemistry. Elsevier, pp. 225-272.

Gent, R., Menendez Alvarez, M., Garcia Iglesias, J., Taraño Alvarez, J., 2005. Offshore occurrences of heavymineral placers, Northwest Galicia, Spain. Marine Georesources and Geotechnology 23, 39-59.

GEOTRACES, 2010. Sampling and Sample handling Protocols for GEOTRACES Cruises. http://www.obsvlfr.fr/GEOTRACES/libraries/documents/Intercalibration/Cookbook.pdf. GEOTRACES Standards and Intercalibration Committee.

GESAMP, 1987. Land/sea boundary flux of contaminants: contributions from rivers. Reports and Studies No. 32. IM0, FAO, UNESCO, WMO, WHO, IAEA, UN, UNEP. Group of Experts on the Scientific Aspects of Marine Pollution, Paris.

Gibbons, W., Moreno, T., 2002. The Geology of Spain. Geological Society, London, p. 632.

Goudie, A., 2004. Encyclopedia of geomorphology. Routledge, London.

Hammond, D., 2001. Pore water chemistry, in: Steele, J., Thorpe, S., Turekian, K. (Eds.), Encyclopedia of Ocean Sciences. Academic Press, San Diego, pp. 2263-2271.

Huettel, M., Ziebis, W., Foster, S., Luther III, G.H., 1998. Advective transport affecting metal and nutrient distributions and interfacial fluxes in permeable sediments. Geochimica et Cosmochimica Acta 62, 613631.

IGME, 1977. Mapa geológico de España. Hoja de Cariño (1:50.000) No. 1 (6-2).

Kener, M., Wallmann, K., 1992. Remobilization events involving Cd and Zn from intertidal flat sediments in the Elbe estuary during the tidal cycle. Estuarine, Coastal and Shelf Science 35, 371-393.

Knee, K.L., Paytan, A., 2011. Submarine Groundwater Discharge: A Source of Nutrients, Metals, and Pollutants to the Coastal Ocean, in: Wolanski, E., McLusky, D.S. (Eds.), Treatise on Estuarine and Coastal Science, vol. 4. Waltham: Academic Press., pp. 205-234.

Li, Y.H., Gregory, S., 1974. Diffusion of ions in sea water and in deep-sea sediments. Geochimica et Cosmochimica Acta 38, 703-714.

Man, K.-W., Zheng, J., Leung, A.P.K., Lam, P.K.S., Lam, M.H.-W., Yen, Y.-F., 2004. Distribution and behavior of trace metals in the sediment and porewater of a tropical coastal wetland. Science of The Total Environment 327, 295-314.

Marcos, A., 2004. Zona Asturooccidental-Leonesa, in: Vera, J.A. (Ed.), Geología de España. SGE-IGME, Madrid, pp. 49-68.

Martin, J.M., Burton, J.D., Eisma, D., 1980. River inputs to the ocean systems, Proceedings of a SCOR/ACMRR/ECOR/IAHS/UNESCO/CMG/IABO/IAPSO review and workshop, p. 384.

Meysman, F.J.R., Galaktionov, O.S., Gribsholt, B., Middelburg, J.J., 2006. Bio-irrigation in permeable sediments: An assessment of model complexity. Journal of Marine Research 64, 589-627.

Morace, J.L., Fuhrer, G.J., Rinella, J.F., Mckenzie, S.W., 1999. Surface-Water-Quality Assessment of the Yakima River Basin, Washington: Overview of Major Findings, 1987-91. U.S. Geological Survey. WaterResources Investigations Report 98-4113.

Olías, M., Cánovas, C.R., Nieto, J.M., Sarmiento, A.M., 2006. Evaluation of the dissolved contaminant load transported by the Tinto and Odiel rivers (South West Spain). Applied Geochemistry 21, 1733-1749.

Ospina-Alvarez, N., Caetano, M., Vale, C., Santos-Echeandía, J., Bernárdez, P., Prego, R., 2014. Exchange of nutrients across the sediment-water interface in intertidal ria systems (SW Europe). Journal of Sea Research 85, 349-358.

Otero, X.L., Huerta-Diaz, M.A., Macias, F., 2000. Heavy metal geochemistry of saltmarsh soils from the Ria of Ortigueira (mafic and ultramafic areas, NW Iberian Peninsula). Environmental Pollution 110, 285296.

Ott, R.L., Longnecker, M.T., 2008. An introduction to statistical methods and data analysis, 6th ed. Brooks/Cole, Cengage Learning, Belmont, CA.

Prego, R., Caetano, M., Ospina-Alvarez, N., Raimundo, J., Vale, C., 2014. Basin-scale contributions of Cr, Ni and Co from Ortegal Complex to the surrounding coastal environment (SW Europe). Science of The Total Environment 468-469, 1-10. 
Prego, R., Cobelo-Garcia, A., 2003. Twentieth century overview of heavy metals in the Galician Rias (NW Iberian Peninsula). Environmental Pollution 121, 425-452.

Prego, R., Cotte, M.-H., Cobelo-Garcia, A., Martin, J.-M., 2006. Trace metals in the water column of the Vigo Ria: Offshore exchange in mid-winter conditions. Estuarine, Coastal and Shelf Science 68, 289-296.

Quevauviller, P.H., Rauret, G., Lopez-Sanchez, J.F., Rubio, R., Ure, A.M., Muntau, H., 1997. The certification of the EDTA-extractable contents (mass fractions) of $\mathrm{Cd}, \mathrm{Cr}, \mathrm{Ni}, \mathrm{Pb}$ and $\mathrm{Zn}$ in sediment following a threestep sequential extraction procedure. Report EUR 17554 EN. Brussels: European Commission.

Rae, J.E., 1997. Trace metals in deposited intertidal sediments, in: Jickells, T.D., Rae, J.E. (Eds.), Biogeochemistry of Intertidal Sediments. Cambridge University Press, Cambridge, pp. 16-41.

Rantala, R., Loring, D., 1975. Multi-element analysis of silicate rocks and marine sediments by atomic absorption spectrophotometry. Atomic Absorption Newsletter 14, 117-120.

Rivera-Duarte, I., Flegal, A.R., 1997. Porewater gradients and diffusive benthic fluxes of Co, Ni, $\mathrm{Cu}, \mathrm{Zn}$, and Cd in San Francisco Bay. Croatica Chemica Acta 70, 389-417.

Roberts, L.C., Hug, S.J., Dittmar, J., Voegelin, A., Kretzschmar, R., Wehrli, B., Cirpka, O.A., Saha, G.C., Ashraf Ali, M., Badruzzaman, A.B.M., 2010. Arsenic release from paddy soils during monsoon flooding. Nature Geoscience 3, 53-59.

Salminen, R., 2005. Geochemical Atlas of Europe. Part 1: Background Information, Methodology and Maps. Espoo, Geological Survey of Finland. http://www.gtk.fi/publ/foregsatlas/index.php.

Santos-Echeandia, J., Prego, R., Cobelo-Garcia, A., Millward, G., 2009. Porewater geochemistry in a Galician Ria (NW Iberian Peninsula): Implications for benthic fluxes of dissolved trace elements ( $\mathrm{Co}, \mathrm{Cu}, \mathrm{Ni}, \mathrm{Pb}, \mathrm{V}$, Zn). Marine Chemistry 117, 77-87.

Silva, N., Haro, J., Prego, R., 2009. Metals background and enrichment in the Chiloé Interior Sea sediments (Chile). Is there any segregation between fjords, channels and sounds? Estuarine, Coastal and Shelf Science 82, 469-476.

Simon, N.S., 1989. Nitrogen cycling between sediment and the shallow-water column in the transition zone of the Potomac river and estuary. II. The role of wind driven resuspension and adsorbed ammonium. Estuarine, Coastal and Shelf Science 28, 531-547.

Torre-Enciso, E., 1958. Current state of knowledge of Galician rias (in Spanish: Estado actual del conocimiento de las rías gallegas), Homaxe a R. Otero Pedrayo. Ed. Galaxia, Vigo, Spain., pp. 237-250.

Tuncer, G., Tuncel, G., Balkas, T.I., 2001. Evolution of metal pollution in the Golden Horn (Turkey) sediments between 1912 and 1987. Marine Pollution Bulletin 42, 350-360.

US-EPA, 1985. Health Assessment Document for Nickel. Final Report EPA 600/8-83/012F, Washington DC, p. 434.

US-EPA, 1996. Method 1669: Sampling Ambient Water for Trace Metals at EPA Water Quality Criteria Levels. U.S. Environmental Protection Agency, Office of Water. EPA-821/R-95-034.

Viers, J., Dupré, B., Gaillardet, J., 2007. Chemical composition of suspended sediments in World Rivers: New insights from a new database. Science of The Total Environment 407, 853-868.

Yücesoy, F., Ergin, M., 1992. Heavy-metal geochemistry of surface sediments from the southern Black Sea shelf and upper slope. Chemical Geology 99, 265-287.

Zabel, M., Dahmke, A., Schulz, H., 1998. Regional distribution of diffusive phosphate and silicate fluxes through the sediment-water interface: the eastern South Atlantic. Deep Sea Research Part I: Oceanographic Research Papers 45, 277-300. 


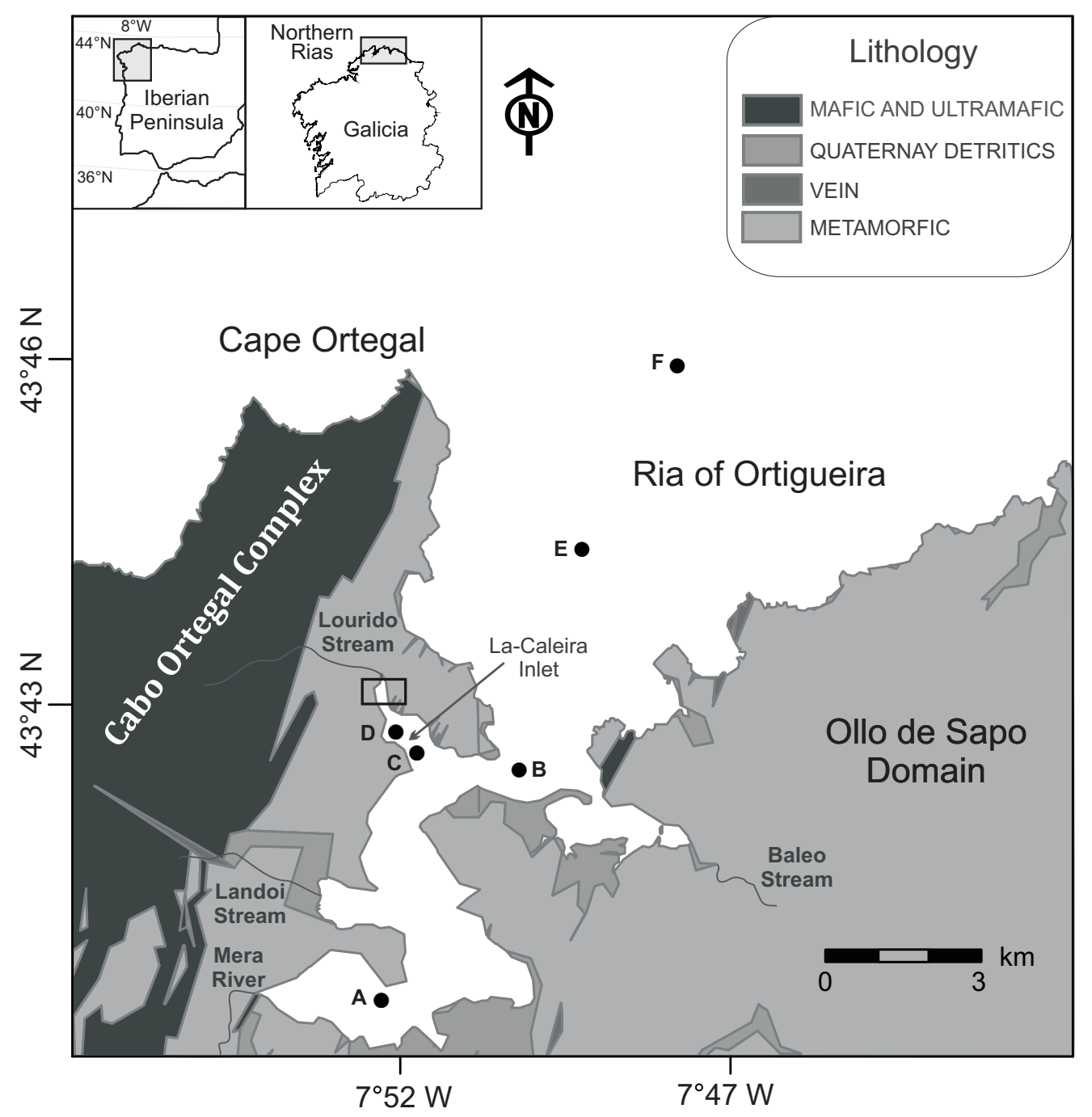

Figure 1. Lithological map of the Ria of Ortigueira. The rectangular area at La Caleira Inlet shows the location of the water-sediment sampling station and black circles indicate the position of the surface sediment samples. Lithology map was obtained from the Spatial Data Infrastructure of Galicia.

http://sitga.xunta.es/sitganet/index.aspx?lang=gl 


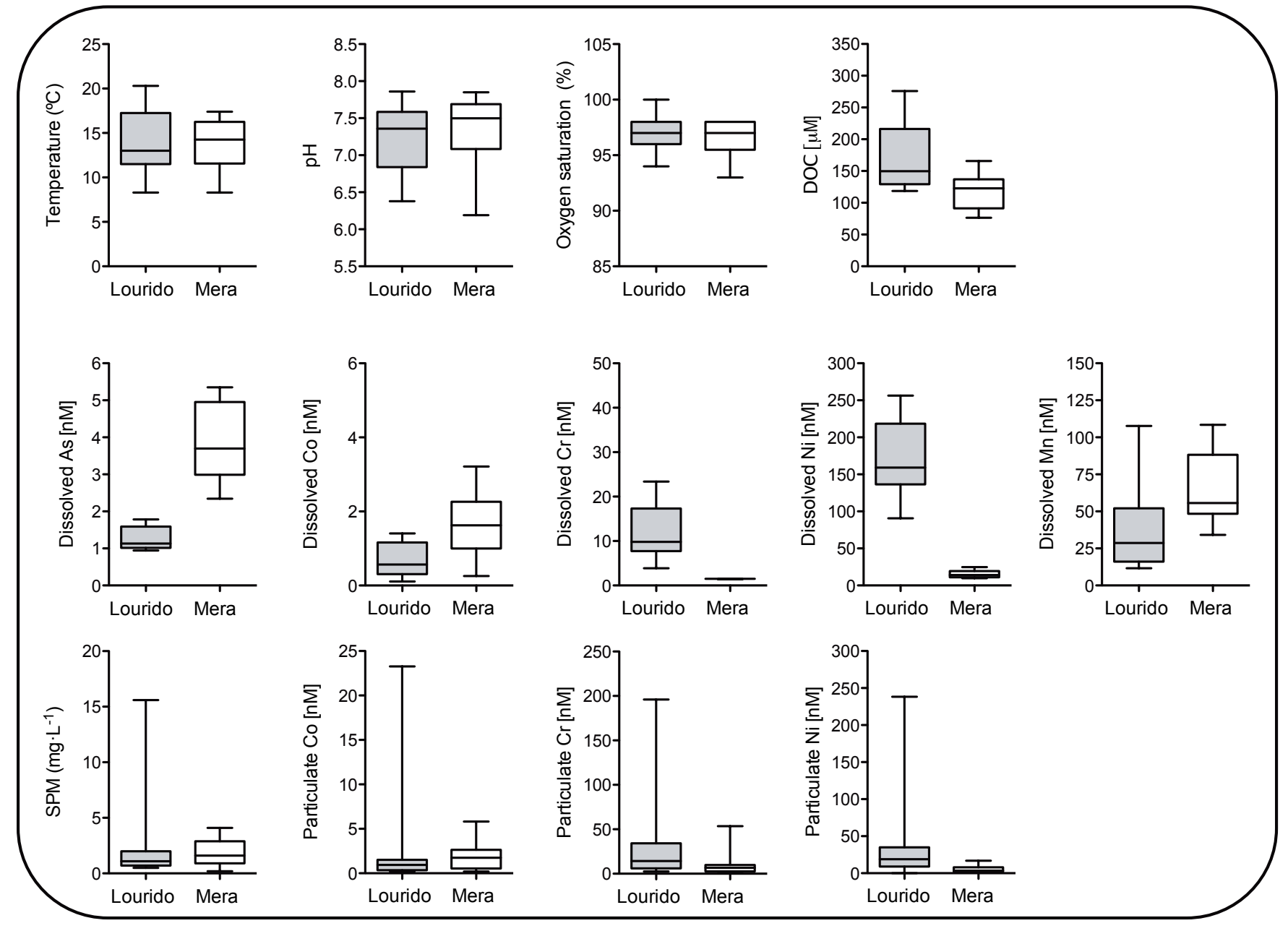

Figure 2. Box and whisker plots of master variables measured in the Lourido and Mera Rivers during 2008 $(n=16)$. Concentrations of particulate trace metals were calculated multiplying metal content in the SPM by SPM concentration in the river water. Horizontal lines correspond to the median and the edges of the boxes of the 25 th and 75 th percentiles respectively. Whiskers show the minimum and maximum values. 

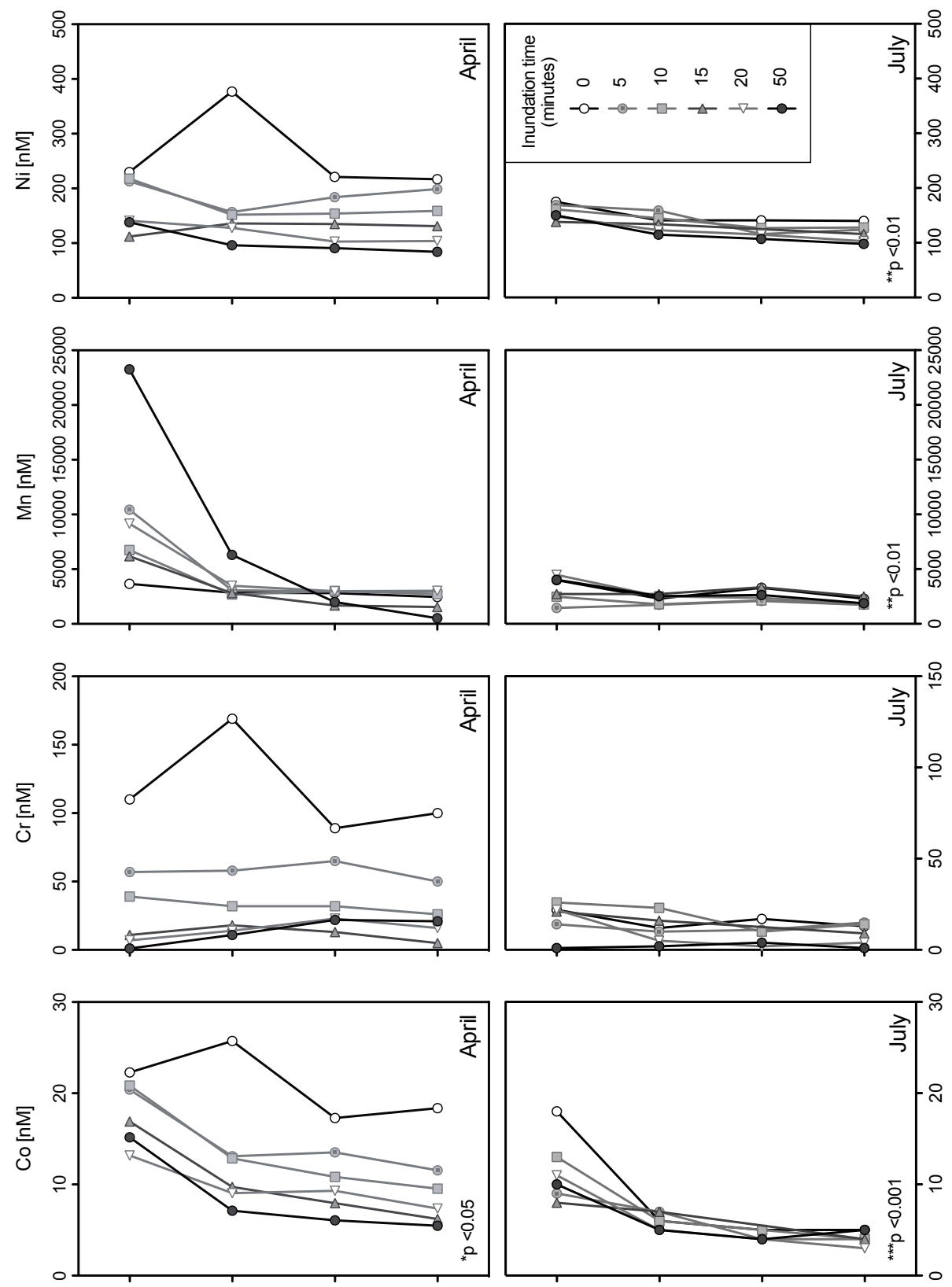

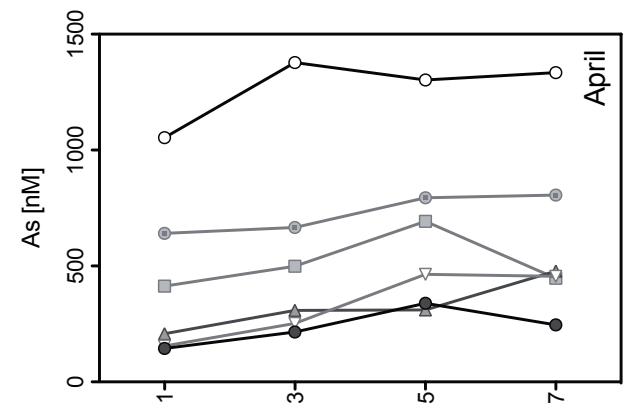

(u०) पldəO

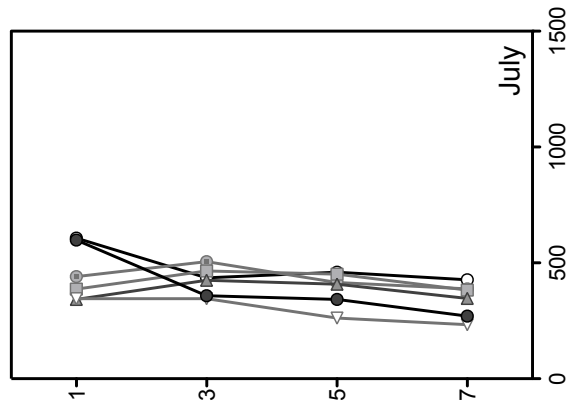

(що) чұdə0

Figure 3. Vertical profiles of trace elements (nM) in sediment pore waters of the Ria of Ortigueira at air-exposed conditions during April and July 2008. ${ }^{*}$ p-value in the left corner indicates significant differences through sediment layers (Kruskal-Wallis test). 

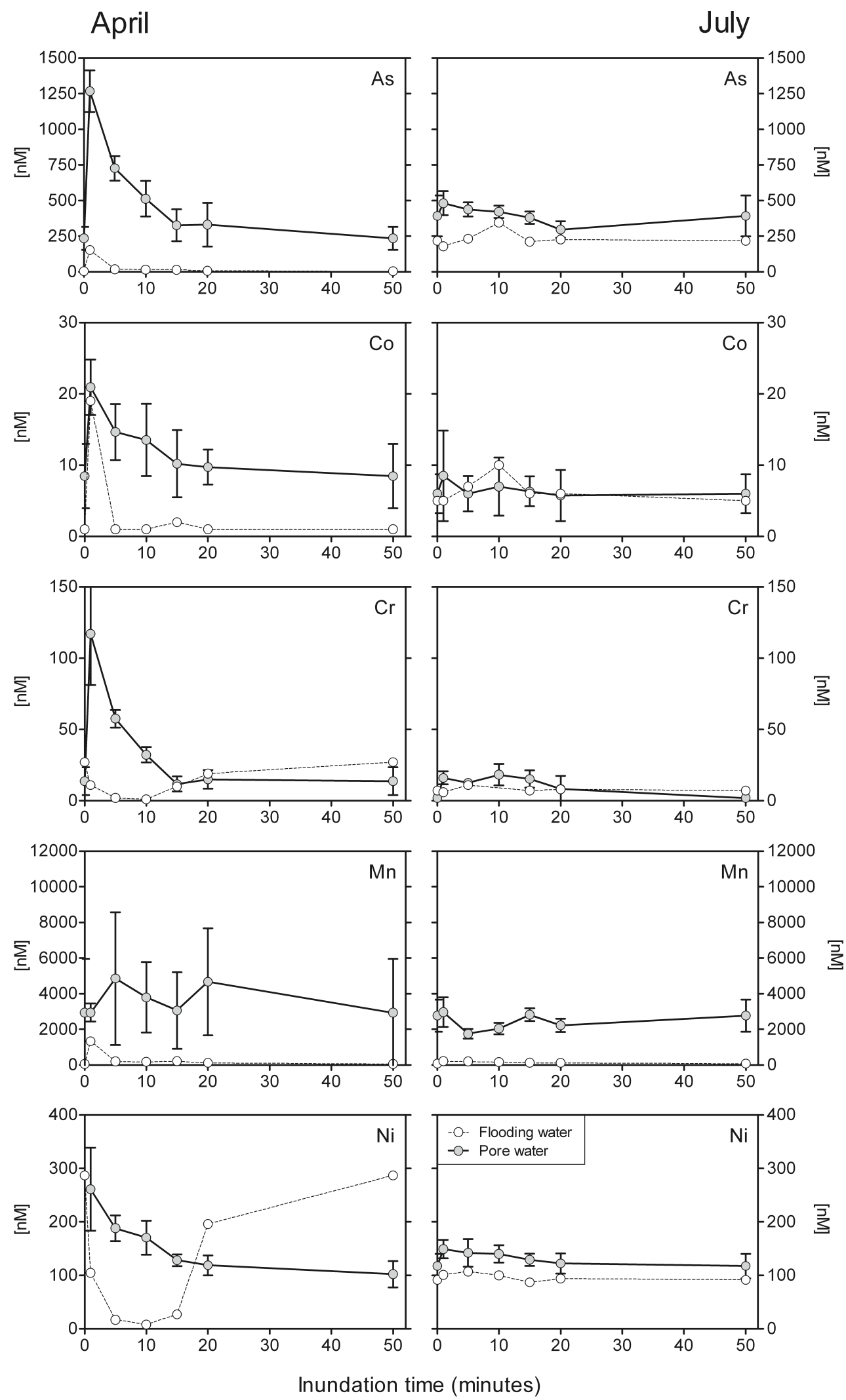

Figure 4. Temporal evolution of dissolved trace elements (nM) in flooding and pore waters at the Ria of Ortigueira in April and July 2008. Pore water values correspond to the mean concentration in the layers $(n=4)$ of the first $8 \mathrm{~cm}$ of the sediment core. Vertical lines indicate standard deviation. Missing points correspond to samples where the volume extracted after centrifugation was not enough for analysis. 


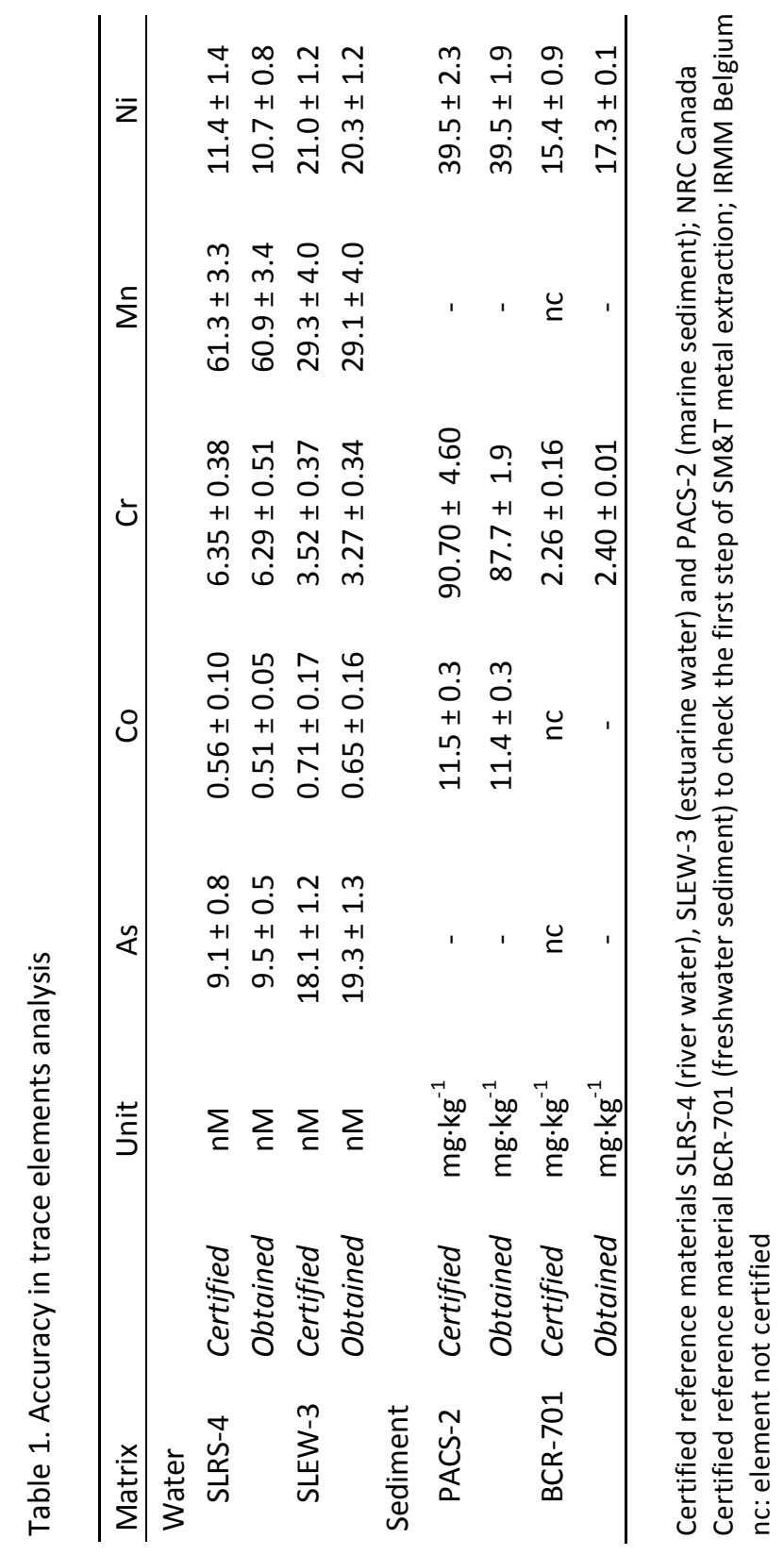


Table 2. Extrapolated diffusion coefficients of trace elements at infinite dilutions according to the water temperature during sampling

\begin{tabular}{lcccccccc}
\hline Month & Temperature & Salinity & Coefficient & $\mathrm{As}^{(\mathrm{a})}$ & $\mathrm{Co}^{(\mathrm{b})}$ & $\mathrm{Cr}^{(\mathrm{b})}$ & $\mathrm{Mn}^{(\mathrm{b})}$ & $\mathrm{Ni}^{(\mathrm{b})}$ \\
\hline April & 9.6 & 0.4 & $\mathrm{D}_{\mathrm{j}}^{0}\left(\times 10^{-6} \mathrm{~cm}^{2} \mathrm{~s}^{-1}\right)$ & 3.84 & 4.71 & 1.45 & 2.64 & 4.50 \\
July & 19.1 & 30.1 & $\mathrm{D}_{\mathrm{j}}^{*}\left(\times 10^{-6} \mathrm{~cm}^{2} \mathrm{~s}^{-1}\right)$ & 7.18 & 5.69 & 3.97 & 5.61 & 5.59 \\
\hline
\end{tabular}

$D_{j}{ }^{0}$ correspond to coefficients calculated for water and $D_{j}{ }^{*}$ to coefficients calculated for sea water (a) Based on Roberts et al. 2010, ${ }^{(b)}$ Based on Li and Gregory (1974) 


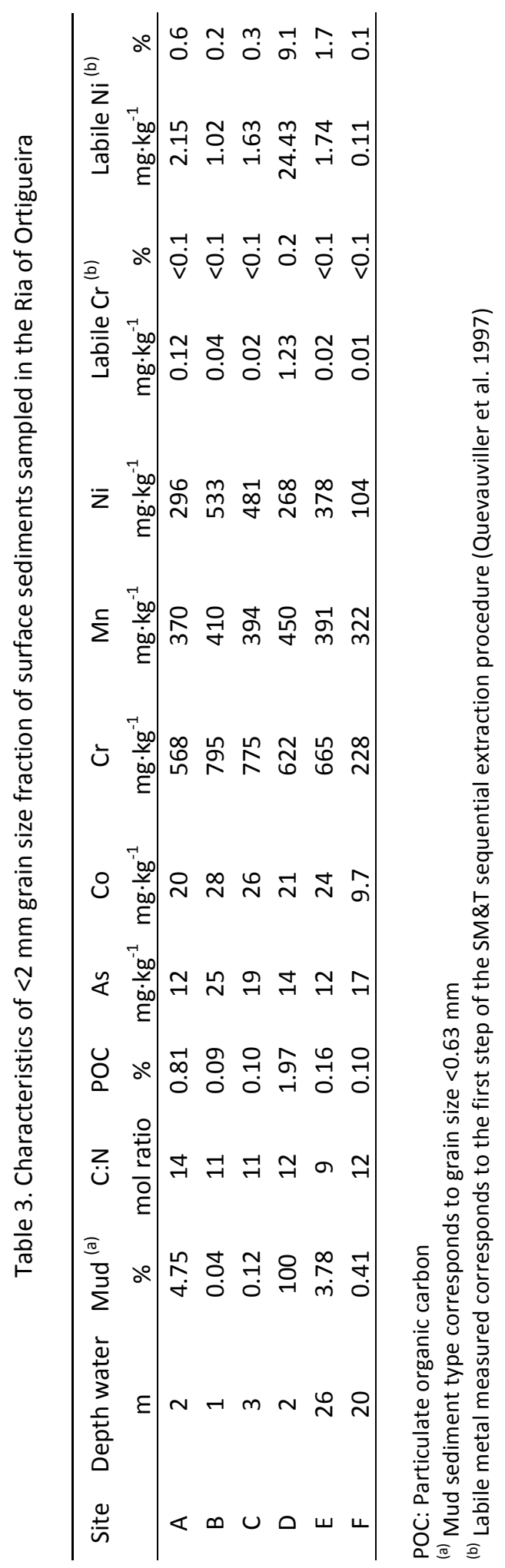


Table 4. Dissolved trace element fluxes $\left(\mu \mathrm{mol} \cdot \mathrm{m}^{-2} \cdot \mathrm{d}^{-1}\right)$ from freshwater and sediments to LaCaleira Inlet. Positive values indicate exportation from the river or sediment to the inlet water.

\begin{tabular}{|c|c|c|c|c|c|c|}
\hline & \multicolumn{2}{|c|}{ Lourido River } & \multicolumn{4}{|c|}{ Sediment } \\
\hline & \multicolumn{2}{|c|}{ Average fluxes } & \multicolumn{2}{|c|}{ Diffusive fluxes } & \multicolumn{2}{|c|}{ Tidal induced transport } \\
\hline & January-March & May-July & $10^{\text {th }}$ April & $21^{\text {st }}$ July & $10^{\text {th }}$ April & $21^{\text {st }}$ July \\
\hline As & 0.034 & 0.035 & -0.391 & -0.564 & 12 & 55 \\
\hline Co & 0.017 & 0.032 & -0.008 & -0.006 & 1.38 & 1.36 \\
\hline $\mathrm{Cr}$ & 0.260 & 0.600 & -0.010 & 0.004 & 16 & 5.1 \\
\hline $\mathrm{Mn}$ & 0.440 & 0.990 & -6.606 & -4.272 & 129 & 46 \\
\hline $\mathrm{Ni}$ & 4.650 & 7.300 & 0.011 & -0.059 & 166 & 8.6 \\
\hline
\end{tabular}




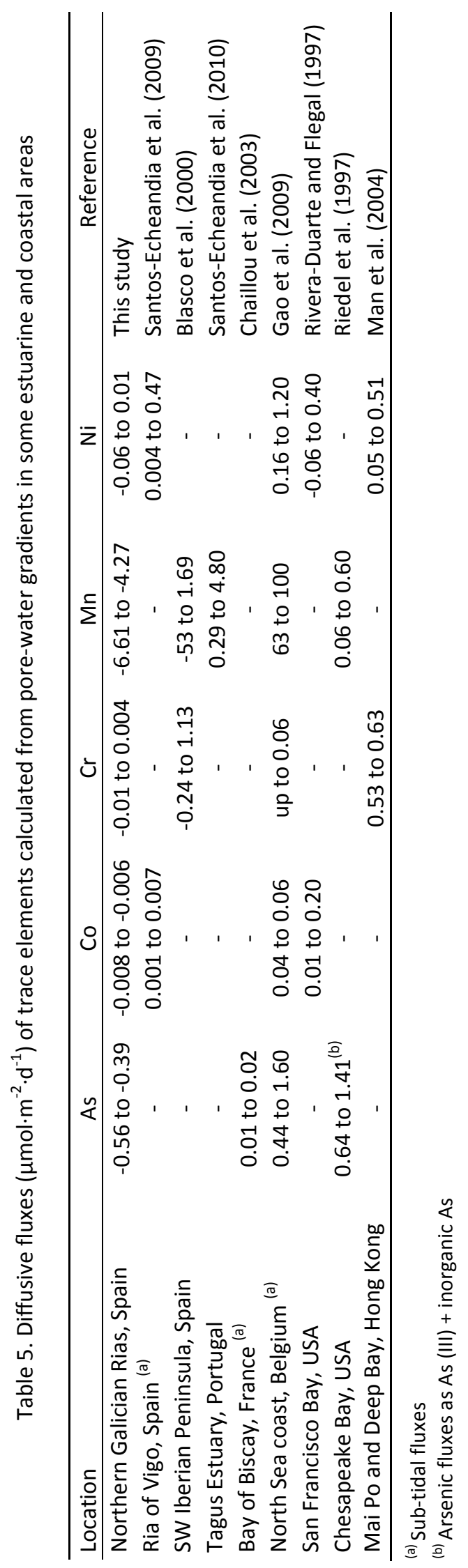

